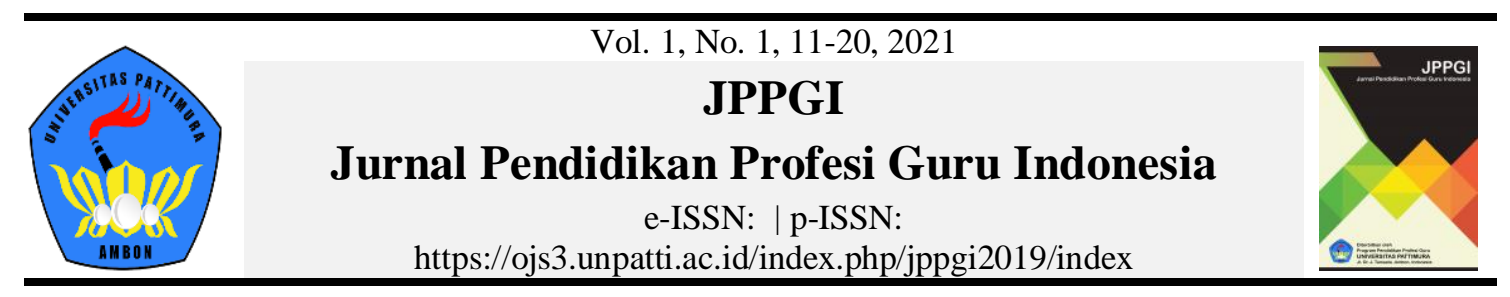

\title{
How to Create a Good Test
}

\author{
Izaak Hendrik Wenno $^{1 *}$, David Tuhurima ${ }^{1}$, Yance Manoppo ${ }^{2}$ \\ ${ }^{1}$ Department of Physics Education, Faculty of Teacher Training and Education, Universitas Pattimura- \\ Ambon, Indonesia \\ ${ }^{2}$ Department of Chemical Education, Faculty of Teacher Training and Education, Universitas Pattimura- \\ Ambon, Indonesia \\ *Corresponding e-mail: wennoiz@yahoo.co.id
}

Received: 06 August $2020 \quad$ Accepted: 14 November $2020 \quad$ Online Published: 08 February 2021

\begin{abstract}
Assessment is a very important part of a learning process. To conduct the assessment, teachers have to design a test. To retrieve a quality of a test, a physics teacher needs to do the items analysis. There are several ways of doing items analysis which including the analysis of difficulty index, discrimination index, and analysis of the validity and reliability. This research is a descriptive study that aims to describe systematically and accurate information on the actual situation in this case about the difficulty index, discrimination index, validity and reliability of the items. The variables analyzed were the quality of teacher-made tests physics. The results of this study indicate that physics teacher-made tests have low validity, reliability moderate or medium, high difficulty index, and poor discrimination index
\end{abstract}

Keywords: Assessment, Test, Physics learning

To cite this article:

Wenno, I. H., Tuhurima, D., \& Manoppo, Y. (2021). How to create a good test. JPPGI: Jurnal Pendidikan Profesi Guru Indonesia, 1(1), 11-20.

\section{INTRODUCTION}

Learning process is a process in wich teachers and student do an activities of teach and learn and consists of the planning, implementation, and evaluation (Berliner, 2005). In teaching and learning activities, teachers need to conduct an evaluation to determine the extent to which the effectiveness of a learning process (Klenowski, 2009). Assessment is an important aspect in the evaluation of teaching and learning. Assessment of learning outcomes is one type of evaluation that teachers can do to determine the success of teaching and learning process (Wiliam, 2011). Assessment of learning outcomes is intended to determine or assess the student's mastery level during learning or gaining knowledge presented by the teacher (Ballard \& Bates, 2008).

Assessment provides two functions for both students and teachers(Richmond, Salazar, \& Jones, 2019). The benefit of assessment for students is knowable extent of their mastery of the subject matter they have taught (Kordestani Moghaddam, Khankeh, Shariati, Norcini, \& Jalili, 2019). For teachers, the assessment results can be a source of information about the success or failure of the learning that has been done, and precisely whether or not the method used. Assesment also give some benefit for instance. In this case the school as a basis for learning progress report and decision-making of student 
success in the form of education report. The assessment results can be used as a basis for further actions and remedial measures for further learning (Koloi-Keaikitse, 2017). Assessment of learning outcomes can be done by using test and non test technique. Test technique is a technique that is done to diagnose or measure the mastery level of student toward the subject matter they have learned. Test technique is a systematically structured procedure to measure the ability of student (Genlott \& Grönlund, 2013).

Tests technique using test item as the instrument. These item were also known as a standardized test and teacher made test. In Indonesia a standardized test items usually used at the national exame either at primary education level or secondary level. Teacher-made tests are usually made by the teacher to evaluate the success of the learning process carried out by the teacher. This test is generally limited to certain subjects, certain classes and certain schools (Hartell \& Strimel, 2019).

A test is qualified if it meets certain criteria. Are several criteria that can be used to express a quality test or not (Kapur et al., 2017). These criteria are reliability, validity, objectivity, practical, and economical (Gyll \& Ragland, 2018). Other criteria that can be assessed from a test is the level or index of difficulty, and discriminating power of items.

A test is considered valid if the test can measure what it will be measured. In addition, a test is reliable if the tests show the accuracy to measure what is measurable, or the test can give the same result even if performed at different times with different subjects. Test must also be objective. This means that the test should actually measure the ability of students regardless of their background knowledge and abilities of students. In addition, the objectivity of the tests are also associated with the scoring of the test results (Alonso, Lopez, Manrique, \& Vines, 2008).

In physics learning, a physics teacher is also required to create or compile test questions. Physics subject matter in $10^{\text {th }}$ grade of Senior High School includes many aspects such as measurement, rectalinear motion, circular motion, particle dynamics, optical instruments, heat and temperature, dynamic electric, and electromagnetic waves. To determine students' mastery of such materials, teachers need to make and develop a test.

First State Leihitu Senior High School is one secondary school in Leihitu Central Maluku district. Based on the observation in this school, the students learning achievement in physics was not good considered. Allegedly, poor physics student learning outcomes related to the problems given to students at the end of semester, or the test were given not in accordance with the student's ability. Thus, the purpose of this study was to determine the quality of teacher-made tests to $10^{\text {th }}$ grade that existed at the $1^{\text {st }}$ state senior high school of Leihitu Regency.

\section{METHOD}

This study included descriptive research with survey approach that aims to describe systematically and accurately about the real situation and gather the necessary data in relation to the quality of teacher-made tests. The experiment was conducted in $1^{\text {st }}$ State Senior High School in Leihitu Central Maluku regency. The object of this research is summative test items of Physics of $10^{\text {th }}$ grade during 2014/2015 academic calendar. The item was 30 multiple-choice, and 5 essay followed by 120 students.

Technique for data collecting in this research was documentation techniques which include summative test items of Physics. Besides these summative test item, keys 
answer and student worksheet test results also collected for items analysis. Analysis of the validity and reliability of items was performed with SPSS version 18.0.

The validity of multiple choice items was based on the value of biserial point correlation, while the validity of essay items based on the description of the ProductMoment correlation values. For both point biserial and product Moment correlation were categorized as follows.

$$
\begin{array}{lll}
0,800-1,000 & : & \text { very high } \\
0,600-0,799 & : & \text { high } \\
0,400-0,599 & : & \text { medium } \\
0,200-0,399 & : & \text { low } \\
0,000-0,199 & : & \text { very low }
\end{array}
$$

Interpretation of the reliability of multipe choice items based on the value of KR20 formula, while for essay items was based on the Alpha Cronbach coeficient. If the value of KR20 and Alfa Cronbach was more than 70, the items were categorized as high reliability.

The difficulty index of item was conducted with the formula proposed (Arikunto, 2013)

$$
P=\frac{B}{J S}
$$

Where: P : Difficulty Index

B: number of student with correct answer

Js: number of all student (testee)

Classification of difficulty index was based on the guidelines as proposed (Sudjana, 211) i.e:

$$
\begin{aligned}
& \text { P: 0,00- 0,30: difficult } \\
& \text { P: 0,30-0,70: medium } \\
& \text { P: 0,70-1,00: easy }
\end{aligned}
$$

To determine the discriminating power of each items, the formula as proposed by Arikunto [14] as follows:

$$
D=\frac{B_{A}}{J_{A}}-\frac{B_{B}}{J_{B}}=P_{A}-P_{B}
$$

Where:

D : Discriminating power of item

JA : number of student on upper group

JB : number of student on lower group

BA : number of upper group with correct answer

BB : number of lower group with correct answer

PA : proportion of upper group with correct answer

PB : proportion of lower group with correct answer 
The discriminating power of items were categorized following the criteria proposed (Arifin, 2013) as follows.

Range of discrimanting power

$0,00-0,19$

$0,20-0,29$

$0,30-0,39$

0,40 or more
Category

Poor

Medium

Good

very good

\section{RESULT AND DISCUSSION}

As seen in Table 1, the 30 multiple choise of items shows variation in validity wich is range in five category i.e very low ( 8 items), low ( 2 items), medium ( 7 items), high (5 items), and very high ( 8 items). For the essay items show that all item has a very high validity, while the reliability for both multiple choise items and essay items show a medium category in reliability. The percentage of multiple choice items validity was shown in Figure 1.

Table 1. The validity and reliability of items

\begin{tabular}{|c|c|c|c|c|c|c|}
\hline $\begin{array}{c}\text { Type of } \\
\text { items }\end{array}$ & Sum of items & $\begin{array}{l}\text { Num. of } \\
\text { items }\end{array}$ & Validity & Category & Reliability & Category \\
\hline \multirow{30}{*}{$\begin{array}{l}\text { Multiple } \\
\text { choice }\end{array}$} & \multirow{30}{*}{30 Items } & 1 & 0.00 & Very low & 0.511 & Medium \\
\hline & & 2 & 0.495 & Medium & 0.511 & Medium \\
\hline & & 3 & 0.768 & High & 0.511 & Medium \\
\hline & & 4 & 0.458 & Medium & 0.511 & Medium \\
\hline & & 5 & 0.112 & Very low & 0.511 & Medium \\
\hline & & 6 & 0.080 & Very low & 0.511 & Medium \\
\hline & & 7 & 0.737 & High & 0.511 & Medium \\
\hline & & 8 & 0.140 & Very low & 0.511 & Medium \\
\hline & & 9 & 0.488 & Medium & 0.511 & Medium \\
\hline & & 10 & 0.963 & Very high & 0.511 & Medium \\
\hline & & 11 & 0.813 & Very high & 0.511 & Medium \\
\hline & & 12 & 0.927 & Very high & 0.511 & Medium \\
\hline & & 13 & 0.757 & High & 0.511 & Medium \\
\hline & & 14 & 0.544 & Medium & 0.511 & Medium \\
\hline & & 15 & 0.621 & High & 0.511 & Medium \\
\hline & & 16 & 0.149 & Very low & 0.511 & Medium \\
\hline & & 17 & 0.957 & Very high & 0.511 & Medium \\
\hline & & 18 & 0.124 & Very low & 0.511 & Medium \\
\hline & & 19 & 0.392 & Low & 0.511 & Medium \\
\hline & & 20 & 0.917 & Very high & 0.511 & Medium \\
\hline & & 21 & 0.844 & Very high & 0.511 & Medium \\
\hline & & 22 & 0.913 & Very high & 0.511 & Medium \\
\hline & & 23 & 0.462 & Medium & 0.511 & Medium \\
\hline & & 24 & 0.548 & Medium & 0.511 & Medium \\
\hline & & 25 & 1.239 & Very high & 0.511 & Medium \\
\hline & & 26 & -0.154 & Very low & 0.511 & Medium \\
\hline & & 27 & 0.328 & Low & 0.511 & Medium \\
\hline & & 28 & 0.543 & Medium & 0.511 & Medium \\
\hline & & 29 & 0.608 & High & 0.511 & Medium \\
\hline & & 30 & 0.160 & Very low & 0.511 & Medium \\
\hline \multirow{5}{*}{ Essay } & \multirow{5}{*}{5 items } & 1 & 0.80 & Very high & 0.525 & Medium \\
\hline & & 2 & 0.92 & Very high & 0.525 & Medium \\
\hline & & 3 & 0.93 & Very high & 0.525 & Medium \\
\hline & & 4 & 1.00 & Very high & 0.525 & Medium \\
\hline & & 5 & 0.91 & Very high & 0.525 & Medium \\
\hline
\end{tabular}




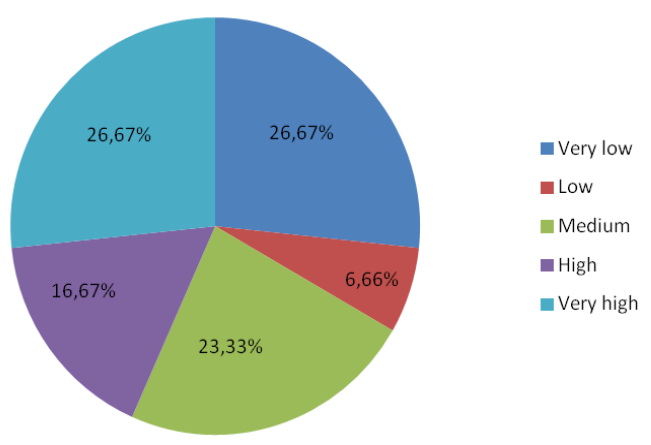

Figure 1. Percentage of multiple choice items validity

As shown in Figure 1, the percentage of multiple choice items validity on very low and very high category was same $(26.67 \%)$, while for high and medium category was vary between $16.67 \%$ and $23.33 \%$, and for low category just about $6.66 \%$. If the validity of the category between very low, low, and medium was joined together, the percentage as much as $56.66 \%$ is greater than about the validity of high and very high (43.34\%). This means that most of the items are not valid.

As also seen in Table 1, the reliability of all items was medium categorized. This result indicates that the validity of multiple choice items of test constructed by Physics teacher in $1^{\text {st }}$ State Senior High School can not considered to be good. Especially for the essay items, its validity was very high and reliability was medium category.

A test was consider to be good or qualify if the validity and reliability of these items was very high category. If the validity and reliability was vary such as what was found on this research, it was allegedly that the teacher still not able and have no skill or more experinece when constructing a test item.

This is understandable because teacher-made tests are tests made by teachers that are used on a limited scale, and is designed to determine the level of students' knowledge in particular. Generally, teacher-made tests have not yet been tested, and also has not been tested for validity and reliability. The factors that affect the reliability and validity of a test is the experience of teachers when constructing a test, the education level of respondents, training analysis and construction items that have been followed by teachers, and the using of Bloom's Taxonomy in the preparation of test items (Gikandi, Morrow, \& Davis, 2011).

The validity and reliability of a test is also influenced by a lot or a small number of items. If the amount of items is much, the item tend to more valid and reliable. Conversely, a little number of items will have a value of the validity and reliability which tend to be low. Another factor that affects the reliability and validity of a test is upon ability students, the student experience, and preparing students for the test to be (Scogin, Kruger, Jekkals, \& Steinfeldt, 2017).

The results of difficulty index analysis of items both for multiple choice questions and essay (Table 2) show that both multiple choice questions and essay have an difficulty index varies from easy, medium, and difficult. From the 30 multiple-choice items, a total of 1 items was easy categories (3.3\%), 13 items Medium category (43.33) and 16 items in a difficult category $(53.33 \%)$. For the essay questions there was only one items is easy categories $(20 \%)$, two items is the medium category (40) and two items also in the difficult category (40\%) (Figure 2). 
Table 2. Difficulty and discrimination index of items

\begin{tabular}{|c|c|c|c|c|c|c|}
\hline $\begin{array}{l}\text { Type of } \\
\text { item }\end{array}$ & Sum of item & $\begin{array}{c}\text { Number } \\
\text { of item }\end{array}$ & $\begin{array}{l}\text { Difficulty } \\
\text { index }\end{array}$ & Category & $\begin{array}{l}\text { Discrimination } \\
\text { index }\end{array}$ & Category \\
\hline \multirow{30}{*}{$\begin{array}{l}\text { Multiple } \\
\text { choice }\end{array}$} & \multirow{30}{*}{30 items } & 1 & 1.0 & Easy & 0.0 & Poor \\
\hline & & 2 & 0.2 & Difficult & 0.31 & Medium \\
\hline & & 3 & 0.6 & Medium & 0.46 & Medium \\
\hline & & 4 & 0.2 & Difficult & 0.27 & Medium \\
\hline & & 5 & 0.1 & Difficult & -0.37 & Poor \\
\hline & & 6 & 0.6 & Medium & 0.02 & Poor \\
\hline & & 7 & 0.3 & Medium & 0.35 & Medium \\
\hline & & 8 & 0.3 & Medium & 0.08 & Poor \\
\hline & & 9 & 0.21 & Difficult & 0.02 & Poor \\
\hline & & 10 & 0.3 & Medium & 0.47 & Good \\
\hline & & 11 & 0.4 & Medium & 0.59 & Good \\
\hline & & 12 & 0.3 & Medium & 0.14 & Poor \\
\hline & & 13 & 0.3 & Medium & 0.04 & Poor \\
\hline & & 14 & 0.1 & Difficult & 0.18 & Poor \\
\hline & & 15 & 0.3 & Medium & 0.41 & Good \\
\hline & & 16 & 0.1 & Difficult & 0.1 & Poor \\
\hline & & 17 & 0.4 & Medium & 0.45 & Good \\
\hline & & 18 & 0.1 & Difficult & 0.12 & Poor \\
\hline & & 19 & 0.5 & Medium & 0.22 & Medium \\
\hline & & 20 & 0.2 & Difficult & 0.39 & Medium \\
\hline & & 21 & 0.3 & Medium & 0.49 & Good \\
\hline & & 22 & 0.2 & Difficult & 0.27 & Medium \\
\hline & & 23 & 0.2 & Difficult & 0.1 & Poor \\
\hline & & 24 & 0.3 & Medium & 0.33 & Medium \\
\hline & & 25 & 0.2 & Difficult & 0.35 & Medium \\
\hline & & 26 & 0.03 & Difficult & -0.02 & Poor \\
\hline & & 27 & 0.06 & Difficult & 0.12 & Poor \\
\hline & & 28 & 0.08 & Difficult & 0.18 & Poor \\
\hline & & 29 & 0.1 & Difficult & 0.26 & Poor \\
\hline & & 30 & 0.03 & Difficult & 0.02 & Poor \\
\hline \multirow{5}{*}{ Essay } & \multirow{5}{*}{5 items } & 1 & 0.59 & Medium & 0.37 & Medium \\
\hline & & 2 & 0.29 & Difficult & 0.34 & Medium \\
\hline & & 3 & 0.93 & Easy & 0.27 & Medium \\
\hline & & 4 & 0.39 & Difficult & 0.45 & Good \\
\hline & & 5 & 0.56 & Medium & 0.63 & Good \\
\hline
\end{tabular}

Figure 2. Difficulty index percentage of multiple choice (left) and essay test items (right)

Based on the figure above, we can conclude that multiple choice test has the highest difficulty level, while the essay test has a moderate to high difficulty level. Difficulty level shows the student ability in material understanding that already given by 
the teacher. The more student could answer the test given, it indicates that the student has a lot knowledge about the material tested. Otherwise, the less student answers the test given, indicates that the student have less knowledge about the material that being tested (Talib, Alomary, \& Alwadi, 2018).

A good questions difficulty level should be on moderate category which means that the questions that given is not too easy and also not too difficult, but could estimate student's ability and shows how deep the knowledge, also the understanding over material that being tested (Gamage, Ayres, Behrend, \& Smith, 2019). This research shows that the difficulty level of multiple choice test either the essay test were high also. Assumption to explain the result is that the difficulty of the test given to the student were not because of the test having a high difficulty level, but also could because the student less understanding on the material that being tested, or the material that being tested was too far out of the material that given by the teacher. In other word, the material that being tested was different with the material that taught by the teacher, so that's why there were a lot student wasn`t capable to finish or accomplish that kind of test.

The analysis of per question differ level (Table 2, Figure 3) shows that for multiple choice question, 16 questions were in Bad category (53.33\%), 9 questions were in Good category (16.67\%). For essay test, 3 questions were in Moderate category $(60 \%)$, and 2 questions were in Good category (40\%).

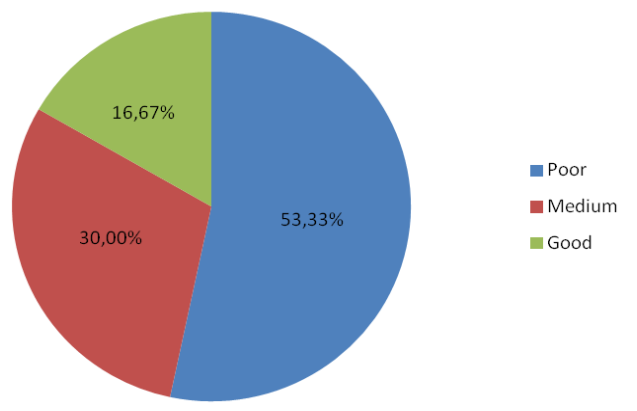

Figure 3. Percentage of differ potential index per questions for multiplechoice test

The results of this study indicate that the discrimination index of multiple choices items that was made by teachers was poor categorized. This means that the question made not able to distinguish between student with high ability and student with low ability. The items are good is it has a high discrimination index, because the items with high discrimination index will be able to distinguish between students with high ability and low ability of students. The higher discriminating index of items was associated with high ability of students in understanding the material taught. With more and understand the material being taught, the possibility of the students gave the correct answer will be even greater (Capan Melser et al., 2020).

Items that can not distinguish the ability of students was caused by several things: the answer key questions that are not appropriate, item has two or more keys right answer, competence measured less clear, humbug does not work the material in question is too difficult, or some students who understand the material assume there is something wrong in the items (Koretsky, Brooks, \& Higgins, 2016). Overall, based on the results of the analysis of the validity, reliability, difficulty index, and the discrimination index of this research show that physics teacher-made tests of the $1^{\text {st }}$ 
State Senior High School in Leihitu with multiple choice questions as much as 30 items and five items of essay, not of good quality.

Some factors can be identified for case, i.e: teachers do not have skills in evaluation included assessment and have no skills and ability to prepare test questions, teacher unable to do the test, and unable to process the test results. In addition, tests were made by the teachers in this school is a test that is compiled by teachers without the help of others/experts, based on materials and specific objectives formulated by the physics teacher to his own class. In general, teacher-made tests are not tested beforehand for many reasons, both involving a matter of time, opportunity, cost, power and also the ability to construct item analysis.

In order to produce a high quality of tests, teachers should do several things, including following the steps and the correct procedures in the preparation of test items. Teachers also have to pay attention to the various rules that exist for the problems resulting form a valid test device. Teachers must recognize the conditions needed for the preparation of a matter.

Steps in the preparation of the matter is: choose a topic or appropriate materials to be tested. Teachers also have to determine which part of the material to be used as a matter of right, whether in the form of multiple choice or description, stuffing, right wrong or to be made in the form of practice exams. Teachers must make the lattice matter by adjusting the indicators of each material . Problem is then written with reference to the indicators in the lattice. After arranging the matter, teachers must make the key answers to multiple choice questions or scoring guidelines for problem description. For multiple choice questions, the teacher must pay attention to the answers given choice should be homogeneous, logical, and only have one correct answer. Teachers also have to examine whether the matter created a whole already meet the standards of good and quality problems.

One of the important things that must be considered in the preparation of the matter is the using of good and right language, not confusing or lead to misinterpretation, so it will affect the selection of students to provide answers. For essay items, the issue must be made according to the indicators that have been set as the lattice matter. Questions also need to have the scope and limitations of a clear answer. The formulation of the question or questions should use the word wonder that demands answers describe, for example : why, explain, describe. The formulation of the sentence about to be communicative and avoid sentences or terms or words that can give rise to multiple interpretations. Things that accompanies the matter, such as tables, diagrams, pictures or something like that should be presented clearly and functioning. Items must be equipped with a key answer or answers the criteria and guidelines for scoring that allows an objective

\section{CONCLUSION}

Based on this results and discussion of this research, it can be concluded that the overall test items made by physics teacher in the $1^{\text {st }}$ State Senior High School in Leihitu is not good quality (low validity, reliability moderate, high difficulty index, and poor discrimination index). .

\section{REFERENCES}

Alonso, F., Lopez, G., Manrique, D., \& Vines, J. M. (2008). Learning objects, learning objectives and learning design. Innovations in Education and Teaching 
International, 45(4), 389-400. https://doi.org/10.1080/14703290802377265

Arikunto, S. (2013). Basics of Educational Evaluation. Jakarta: PT Bumi Aksara

Arifin, Z. (2013). Learning Evaluation. Bandung: PT Remaja Rosdakarya

Ballard, K., \& Bates, A. (2008). Making a connection between student achievement, teacher accountability, and quality classroom instruction. The Qualitative Report, 13(4), 560-580. https://doi.org/10.1021/jp0675911

Berliner, D. C. (2005). The near impossibility of testing for teacher quality. Journal of Teacher Education, 56(3), 205-213. https://doi.org/10.1177/0022487105275904

Capan Melser, M., Steiner-Hofbauer, V., Lilaj, B., Agis, H., Knaus, A., \& Holzinger, A. (2020). Knowledge, application and how about competence? Qualitative assessment of multiple-choice questions for dental students. Medical Education Online, 25(1). https://doi.org/10.1080/10872981.2020.1714199

Gamage, S. H. P. W., Ayres, J. R., Behrend, M. B., \& Smith, E. J. (2019). Optimising Moodle quizzes for online assessments. International Journal of STEM Education, 6(1). https://doi.org/10.1186/s40594-019-0181-4

Genlott, A. A., \& Grönlund, Å. (2013). Improving literacy skills through learning reading by writing: The iWTR method presented and tested. Computers and Education, 67, 98-104. https://doi.org/10.1016/j.compedu.2013.03.007

Gikandi, J. W., Morrow, D., \& Davis, N. E. (2011). Online formative assessment in higher education: A review of the literature. Computers and Education, 57(4), 2333-2351. https://doi.org/10.1016/j.compedu.2011.06.004

Gyll, S., \& Ragland, S. (2018). Improving the validity of objective assessment in higher education: Steps for building a best-in-class competency-based assessment program. The Journal of Competency-Based Education, 3(1), e01058. https://doi.org/10.1002/cbe2.1058

Hartell, E., \& Strimel, G. J. (2019). What is it called and how does it work: examining content validity and item design of teacher-made tests. International Journal of Technology and Design Education, 29(4), 781-802. https://doi.org/10.1007/s10798-018-9463-2

Kapur, V. K., Auckley, D. H., Chowdhuri, S., Kuhlmann, D. C., Mehra, R., Ramar, K., \& Harrod, C. G. (2017). Clinical practice guideline for diagnostic testing for adult obstructive sleep apnea. Journal of Clinical Sleep Medicine, 1313(3), 479-504. https://doi.org/10.5664/jcsm.6506

Klenowski, V. (2009). Assessment for Learning revisited: An Asia-Pacific perspective. Assessment in Education: Principles, Policy and Practice, 16(3), 263-268. https://doi.org/10.1080/09695940903319646

Koloi-Keaikitse, S. (2017). Assessment of teacher perceived skill in classroom assessment practices using IRT Models. Cogent Education, 4(1), 1-14. https://doi.org/10.1080/2331186X.2017.1281202

Kordestani Moghaddam, A., Khankeh, H. R., Shariati, M., Norcini, J., \& Jalili, M. (2019). Educational impact of assessment on medical students' learning at Tehran University of Medical Sciences: A qualitative study. BMJ Open, 9(7), 1-11. https://doi.org/10.1136/bmjopen-2019-031014

Koretsky, M. D., Brooks, B. J., \& Higgins, A. Z. (2016). Written justifications to multiple-choice concept questions during active learning in class. International Journal of Science Education, 38(11), 1747-1765. https://doi.org/10.1080/09500693.2016.1214303

Richmond, G., Salazar, M. del C., \& Jones, N. (2019). Assessment and the Future of 
20 | Jurnal Pendidikan Profesi Guru Indonesia, Vol. 1, No. 1, pp. 11-20, February 2021

Teacher Education. Journal of Teacher Education, 70(2), 86-89. https://doi.org/10.1177/0022487118824331

Scogin, S. C., Kruger, C. J., Jekkals, R. E., \& Steinfeldt, C. (2017). Learning by Experience in a Standardized Testing Culture: Investigation of a Middle School Experiential Learning Program. https://doi.org/10.1177/1053825916685737

Sudjana, N. (2011). Assessment of Teaching Learning Process and Result. Bandung: PT Remaja Rosdakarya

Talib, A. M., Alomary, F. O., \& Alwadi, H. F. (2018). Assessment of Student Performance for Course Examination Using Rasch Measurement Model: A Case Study of Information Technology Fundamentals Course. Education Research International, 2018. https://doi.org/10.1155/2018/8719012

Wiliam, D. (2011). What is assessment for learning? Studies in Educational Evaluation, 37(1), 3-14. https://doi.org/10.1016/j.stueduc.2011.03.001 